\section{ADMINISTRATIVE AND POLITICAL PERSPECTIVES OF THE EU'S REFORM: FOCUS ON PERMANENT STRUCTURED COOPERATION}

\section{Valentin NAUMESCU}

\author{
Valentin NAUMESCU \\ Associate Professor, PhD Habil., Department \\ of International Relations, Faculty of European Studies, \\ 'Babeș-Bolyai' University, Cluj-Napoca, Romania \\ E-mail: valentin.naumescu@ubbcluj.ro
}

\begin{abstract}
Shortly after the Brexit referendum, it became clear that the EU 27 needs structural reforms. The main discourses on the EU's reform usually incorporate political and administrative approaches, reflecting ideological and strategic orientations but also public policy options and governance criteria. One of the most important and debated topics in this process is the Permanent Structured Cooperation (PESCO) in the field of defense, which was constantly rejected by the UK until June 2016.

The aim of this article is to identify, explore and compare the main perspectives with regard to the reform of the European Union, with a focus on PESCO. We take into consideration the views expressed by European political leaders as well as high ranking officials from central administration in the EU Member States but also at NATO level. Based on a qualitative comparative research of the major discourses and projects in the field, this analysis indicates possible directions in which PESCO could advance in the coming years, but also some vulnerabilities, limitations and risks related to European defense and security as a public policy.
\end{abstract}

Keywords: European Union, reform, PESCO, NATO, security. 


\section{Introduction: Why does the EU need reforms?}

In the weeks and months following the shocking result of the Brexit referendum, a number of significant proposals coming from prominent European politicians gave the first indication that the EU 27 is ready to assume essential reforms of its strategy and policies. It was still in the summer and autumn of 2016, before the crucial electoral year 2017 brought encouraging victories for the pro-European candidates in France, Germany and the Netherlands. Facing the perspective of its own disintegration, after the first exit of a Member State, the Union had to act decisively to strengthen its attractiveness and effectiveness among the remaining 27 Member States. Even though we can presume that those documents were conceptualized and prepared before the Brexit referendum, their impact, symbolism and political added-value were very much augmented in the context of the surprising UK decision to leave the European Union.

The first major proposal belonged to the EU High Representative Federica Mogherini who presented in June 2016 the EU's Global Strategy on foreign policy and security, called 'Shared Vision, Common Action: A Stronger Europe'. Later on, in October 2016, the Council adopted its first conclusions on the Global Strategy and decided five priority areas for the next year: 'Resilience building and integrated approach to conflicts and crises; Security and defense; Strengthening the nexus between internal and external policies; Updating existing or preparing new regional and thematic strategies; Stepping up public diplomacy efforts' (Council of the European Union, 2016). It was a clear indication that the EU was already intending to improve its external action, based on a mix of political and public management approaches.

The second reforming project was co-authored by the French and German defense ministers. Ursula Von der Leyen and Jean Yves Le Drian sent in September 2016 a common letter to Brussels for establishing a Defense Union to 'reinforce our solidarity and European defense capabilities in order to more effectively protect the citizens and borders of Europe' (Von der Leyen and Le Drian apud Rettman, 2016). Based on the mechanism of Permanent Structured Cooperation (PESCO) between a certain group of EU Member States, stipulated in the articles 42(6) and 46 of the EU Treaty, any possible development in this sense was repeatedly blocked by the UK until 2016, on the reason of a possible NATO's weakening. Brexit was therefore opening the gates in Brussels for the establishment of PESCO in the field of defense.

The question of the European Union's reform, both in its internal and external dimensions, dominated the post-British referendum era. Moreover, the election of Donald Trump as President of the United States in November 2016 augmented the perception of an urgent need of action in order to save the European Project from the temptations of populism. Several political and public management/administrative approaches focused on the idea of reform and the interests of the citizens, even though in the field of strategic policies such as Common Foreign and Security Policy (CFSP) it is difficult to identify and speak on behalf of the 'interests of the citizens'. Polls are not of a great help, taking into consideration the sophistication of the topics, 
the incomplete information available at public level and the difficulty to 'translate' technical aspects of defense and security into basic public questions.

The purpose of this paper is to identify, explore and compare the main political and administrative perspectives regarding the European Union's reform, with a special focus on the Permanent Structured Cooperation. The research question is what possible directions can take the existing approaches in the field of defense policy and what consequences might have on the future of the European Union. The chosen methodology consists of a qualitative comparative analysis of official documents, political statements and administrative options related to the topic.

The structure of the article comprises four sections: an introduction meant to present the defining aspects with regard to this research, a theoretical framework reviewing the literature of the EU reforms, an empirical research on PESCO as it is profiling nowadays, and finally the concluding remarks.

\section{Theoretical framework}

A vast literature covers the never-ending debate of the European Union's reform. In fact, the EU was from the moment of its foundation in search of the right direction for the next 'reform', in order to respond more and more adequately to permanently renewing challenges and opportunities. The reforming approaches usually pivoted between (neo)functionalism (Haas, 1958), liberal intergovernmentalism (Moravcsik, 1998), and historic institutionalism (Pierson, 1996). It was therefore not the British referendum of 2016 the event that 'invented' the topic of the EU reform, but definitely Brexit poured oil on fire. That is why we consider that the so-called 'refoundation' suggested by the French President Emmanuel Macron (Reuters, 2017) is just a different, spectacular denomination within this long series of reforms. Politicians and high ranking bureaucrats, policy experts and academics but also journalists and civil society contribute to this intense debate of reform.

To give an example of typical academic assertion on the EU crisis and the need of political and administrative reforms, which was also valid in 2010, just after the 'new' Treaty of Lisbon (2009) entered into force, the public was informed that: 'today, the EU sits at a difficult crossroads. Its dramatic increase in policy capacity has yet to be matched with mechanisms of democratic representation or streamlined decision-making, leaving it less than effective and often unloved' (McNamara, 2010). Needless to say this wording could be easily applied for the 1970s or the 1980s as well as for the present context. It does not mean that nothing happened in the European Union since then. The idea that we are heading towards a finality of the European Union, where the organization will eventually meet the perfect shape, functions and structure is obviously a chimera of all political epochs.

Eight years before the quake of Brexit, in his book explaining 'what's wrong with the European Union and how to fix it', Simon Hix made a premonitory remark: 'referendums are a crude and ineffectual mechanism for expressing citizens' preferences on EU policy issues. What is missing is a more open debate about the emerging pol- 
itics inside the Brussels beltway and clearer connections between this politics and citizens' view' (Hix, 2008, p. 5). Hix was right in the sense that he anticipated the risk that a popular consultation on EU policy issues could be distorted by the political interests of the competitors, using a wide arsenal of manipulation, fake news, hiding half of the necessary information etc., so that the ordinary voters do not know in the end what exactly they are voting for or against.

In a book whose title almost tells the essence, 'Reforming the European Union: Realizing the Impossible', the authors speak about the Sisyphean effort of trying to reform the European Union; according to Daniel Finke and Thomas König, 'every three to four years, the EU has tried to assess and reform its institutions, since the mid-1980s to the beginning of the twenty-first century, but with little success. [...] The reason for the slow rate of change was the opposition to far-reaching institutional reform from a minority of political leaders. As expected, the enlargement of 20042007 increased the number of political leaders opposed to reform' (Finke et al., 2012, p. 1). The authors do not specify whether the increased number of political leaders opposing the reform refers necessarily to the ones from the new Member States or to western politicians who criticized the extension to the East or to both categories, but the thesis associates the failure of the reform with some of the political leaders from the Union. Four years before the Brexit referendum, the authors were analyzing the lack of political accountability regarding the significances of the failed referendums for the EU Treaties' ratification in France, Netherlands and Ireland.

In 2014, at the end of the Euro Zone crisis and just when Greece was about to be saved for the second time from bankruptcy, the economists John Peet and Anton La Guardia published their version of 'how the Euro crisis and Europe can be fixed', under the influence of the paradigm 'if the euro fails, Europe fails': 'the euro has been saved, at least for a while. But even as economic output begins slowly to recover, the euro zone remains vulnerable and the wider European projects remain under acute strain' (Peet and La Guardia, 2014, p. 6). The economic approach will remain however one of the main directions of the EU reforms, especially focused on the Eurozone.

As for the administrative perspective, the first observation is that EU Member States have their own national administrative systems, while the idea of European integration in public administration made just a few timid steps. There is no 'administrative pillar' of the European Union, as it happens for instance with the economic and monetary union. Isolated projects such as the Support for Improvement in Governance and Management (SIGMA) tried in the past 25 years to develop a European dimension in reforming the public administration. SIGMA is a joint initiative of the European Union and OECD whose aim is 'to strengthen the foundations for improved public governance, and hence support socio-economic development through building the capacities of the public sector, enhancing horizontal governance and improving the design and implementation of public administration reforms, including proper prioritisation, sequencing and budgeting' (SIGMA, undated).

Based on the so-called SIGMA 'principles of good public administration', Bovaird identifies six horizontal systems of governance, which worked in the past with some 
results in the process of the East Central European countries' integration in the European Union: 'policy making and coordination, civil service and administrative law, public expenditure management, internal financial control systems, public procurement, external audit and public integrity systems' (Bovaird, 2016, pp. 14-15). Nevertheless, the Europeanisation of the public administration is rather a theoretical approach than a real process while the convergence of administrative systems made modest progress. The above mentioned core of European standards is not fully reflected in political decisions neither in old Member States nor in the new ones: 'Given this common administrative law tradition, one could assume that these countries would be able to quickly adapt to the common principles of the [European Administrative Space]. However, it seems that this is not necessarily the case, as administrations and governments often show little willingness to accept the need for real reform and actively promote it' (Cardona and Freibert, 2007, p. 58).

The issue of politicization of the public interests and the relation between politics and the EU policy issues is treated at length in the academic literature. It is one of the arguments saying in its essence that administrative and political approaches of the EU reform cannot be separated. On one hand, 'the articulation of public interests [is seen] as an ingredient of the relationship between the elites and the European citizens and as a tool for policy elites to signal to citizens that their voices are heard or disregarded' (De Bruycker, 2017, p. 615). On the other hand, there are several researches that demonstrate the idea that the EU policy and administrative process is susceptible to be influenced by party pressures, reflected in political and electoral interests (Bølstad, 2015; Toshkov, 2011; Alexandrova, Rasmussen and Toshkov, 2015). This observation is somehow contradicting the old thesis of an alleged EU democratic deficit that used to claim the existence of a detached, isolated 'Eurocracy' making regulations beyond any public interest. In fact, the lesson of Brexit reveals that the risk of insufficiently prepared popular consultations (referendums), when political manipulation and populism are distorting the meanings of a real debate, is even higher than the risk of the traditional EU 'democratic deficit'.

The administrative reforms in the European Union took different directions and shapes in the past decade. One of the interesting attempts to revitalize the policy output was the so-called Kinnock Reform(s), regarding the inner functioning of the European Commission and the increasing role of the middle management, represented by the heads of unit $(\mathrm{HoU})$. Based on an empirical research consisting in a survey of more than $100 \mathrm{HoUs}$, Bauer concluded that, despite of a comprehensive redefinition of the role of the HoU, 'their resource base to focus on policy drafting has been hugely reduced. Negative consequences for the organization's potential to deliver policy draft of high quality are therefore very likely' (Bauer, 2009, p. 459). The idea of transferring more competences to middle management in order to have more administrative input in the European Commission and less political orientation was also approached in a series of researches (Balint, Bauer and Knill, 2008; Kassim et al., 2010; Spence, 2006; Kassim, 2008; etc.). 
More recently, the reform of the European Commission was analyzed in comparative perspective with the reforms of the public sector at national level. As Edoardo Ongaro concluded, 'the 'unique' politico-administrative context of the European Union affected the trajectory of reform of the Commission, compared with trajectories of reform of the public sector at the national level' (Ongaro, 2013, p. 346). This study explains to a large extent why the administrative reforms of the European Union/ European Commission went always much more difficult than any national administrative reform.

The 'administrative direction' seems somewhat abandoned after the Brexit referendum, once the political approaches returned as the main leading forces of the EU reforms. Looking to the so-called 'Macron's Plan' of the EU reform, launched with the occasion of the Sorbonne speech of September 2017, we find a reference to the reform of the European Commission in the sense of a proposed shrink of the College of the Commissioners, from 28 to 15 after the UK's exit. It is however difficult to believe that 12 Member States will accept to remain without a commissioner so that the way from the post-Brexit projected reforms to political decisions and implementation will be again quite long.

\section{Permanent Structured Cooperation (PESCO) in the field of defense}

Under the large umbrella of the reform of the European Union, PESCO in the field of defense seems to be one of the most important envisaged changes. Based on a functionalist perspective, as its own name suggests, PESCO offers a framework for enhanced cooperation of a group of states in the field of defense, with a focus on investment and collaboration in developing European military technologies. The legal basis of PESCO resides in articles 42(6) and 46 as well as Protocol 10 of the EU Treaty.

The idea of a common European defense is not new as its roots date back to the beginning of the Cold War. Following the April 1949 Washington Treaty of establishing the North Atlantic Alliance, the United States and its western European allies began to take into consideration the necessity of rearmament of the Federal Republic of Germany, which at that time was not part of NATO. A certain European form of defense collaboration with West Germany appeared to be the most indicated measure as a first step.

In 1950, the European Defense Community was proposed by the French Prime Minister René Pleven, and the six founding Member States of the European Coal and Steel Community seemed to embark on that direction, signing the Paris Treaty of 1952. The ratification of the Treaty was surprisingly rejected in August 1954 by the French National Assembly, based on an ad-hoc coalition of the Gaullist and communist forces in order to oppose Germany's rearmament. It was the first failure of the idea of a common European defense.

The gradual extension and the success of NATO as a provider of guarantees for the Western Europe's security made useless for decades any discussion with regard to an integrated European form of defense, distinct from the North Atlantic Alliance. 
West Germany joined NATO in 1955, and the question of European security seemed somehow resolved. Lord Ismay, NATO's first Secretary General, explained the reason of the Alliance expressively: 'to keep the Russians out, the Americans in and the Germans down' (NATO, undated). After the UK accession in 1973, the European Economic Communities (EEC) followed by the renamed European Union in 1993 became even more unwilling or incapable to forge a European army.

The British decision to leave the EU reopened the old discussion on a certain form of defense collaboration/union. The process is however difficult and complex, both strategically and politically, not to mention financial, military and administrative aspects. The issue is thorny not only because the overwhelming majority of the EU Member States are also NATO members, but because they have begun to express different strategic views in the field of defense and security, different levels of relations/partnerships with the United States and different positions with regard to the future architecture of the European Union. There are highly ranking officials, especially among the US' closest allies on the Eastern Flank of NATO, who do not give too much credit to the military perspectives of the Defense Union. In Romania, Ambassador Bogdan Aurescu, presidential aid for foreign policy and former Foreign Minister, believes that 'we will never see a European army replacing NATO ... PESCO will just intensify cooperation between EU and NATO. Romania is interested in 10 of the PESCO projects' (Mănoiu, 2017). Poland was even more exigent when it officially joined PESCO, mentioning that Warsaw:

'will participate in PESCO, only under the following conditions: PESCO activities will be implemented on an equal principles with respect to all challenges, including defense of the Eastern Flank. The development of national defense industries will be supported to ensure their competitiveness, innovation and sustainability; Within the PESCO, will not be created any parallel structures, competitive to NATO. Furthermore, all undertaken initiatives will be complement to the capabilities of the Alliance' (Ministry of National Defense of Poland, 2017)

For at least two main reasons the progress and consolidation of PESCO will be difficult, as mentioned before, and these reasons imply the security guarantees - offered by the United States (through NATO's famous article 5) - which PESCO does not mention, and the significant differences of views with regard to the reforms of the European Union. But there are other reasons also.

Firstly, not all EU Member States take part to this initiative. More preciously, in November 2017, 23 Member States signed a joint notification on PESCO and handed it over to the Council and the High Representative. The diplomatic demarche marked a massive affiliation to the initiative from its nascent phase, with the exception of four countries (Denmark, Ireland, Portugal and Malta) out of the EU 27. Republic of Ireland and Portugal joined a little bit later, at the dedicated European Council held on December 11, 2017. The Irish legislature (Dáil Éireann), for instance, adopted in December 2017 a motion in favor of joining PESCO with a majority of 75 to 42 votes. The 
prime minister (Taoiseach) Leo Varadkar declared with the occasion of the debate:

'My view is that a Europe that is worth building is a Europe that is worth defending. For a very long time, all of Europe has relied on the United States to provide for its defense. There are real threats to European security and, over time, rather than relying on the United States to defend Europe and pay for European defense, Europe should provide and pay for its own defense and not be dependent on the United States in the way it has been since 1945.' (Finn, 2017)

Secondly, as the official PESCO notification stipulates, the principles of the permanent structured cooperation combine political commitments ('Level of Ambition') with governance criteria; PESCO is therefore about strategy and policy at the same time. Essentially, the objectives refer to 'an ambitious, binding and inclusive European legal framework for investments in the security and defense of the EU's territory and its citizens [...] the list of 'ambitious and more binding common commitments' the member states have agreed to undertake, including 'regularly increasing defense budgets in real terms in order to reach agreed objectives' [and] proposals on PESCO governance, with an overarching level maintaining the coherence and the ambition of the PESCO, complemented by specific governance procedures at projects level' (Council of the European Union, 2017).

Referring to the new European initiative's strategic dimension, NATO's Secretary General Jens Stoltenberg formulated in diplomatic terms:

'I welcome PESCO because I believe that can strengthen European defense which is good for Europe but also good for NATO. Stronger European defense has the potential to help us increase defense spending, provide new capabilities and also to improve burden-sharing within the Alliance. So this is a way to strengthen the European pillar within NATO. I also welcome the fact that so many European leaders have highlighted or underlined the importance that European defense has to be developed in a way that it's not competing with NATO, but which is complementary to NATO. We don't need duplication, we don't need competition, but what we need is cooperation and a European defense which is complementing NATO'. (Stoltenberg, 2017)

In fact, the NATO official was subtly introducing the main concern related to the relation between PESCO and NATO, behind his encouraging and positive remarks.

With regard to its structure and governance, PESCO has 'a two-layer structure: [1] Council level, responsible for the overall policy direction and assessment mechanism to determine if Member States are fulfilling their commitments. Only PESCO members are voting, decisions are taken by unanimity (except decisions regarding the suspension of membership and entry of new members which are taken by qualified majority). [2] Projects Level: PESCO's effectiveness will be measured by the projects it will develop. Each project will be managed by those Member States that contribute to it' (European Union External Action, 2017).

The launch of PESCO in 2017 was seen quite differently: as a success or as a semi-failure. Those who saw the large number of EU member states joining the initia- 
tive as a good sign believe that the more interest in PESCO show the Member States, the better is for this new policy. On the contrary, those who believe that the massive formal affiliation is not necessarily a good perspective think that the dilution of PESCO in an almost all-in EU policy will eventually weaken the effectiveness of the program. The idea that PESCO decisions will be taken on a unanimity basis by 25 member states makes in fact the Permanent Structured Cooperation to look more and more like any other EU policy.

Rather skeptical, Nick Witney, the first chief executive of the European Defense Agency, currently senior analyst at the think tank European Council on Foreign Relations is wondering 'how often can the EU fail to deliver on its defense ambitions before the whole notion of an EU 'defense project' becomes terminally discredited? [...] The concept of the advance-guard has been replaced with that of the convoy; and the Poles, who oppose the whole idea of European defense, are not even troubling to conceal that their purpose in joining the convoy is to slow it down. [...] The commitments have simply been watered down so as to become virtually meaningless' (Witney, 2017). The idea that the reluctant EU member states joined PESCO in order to keep it under control - because of the unanimity rule of decision - and to limit its expansion is also emphasized by other authors and analysts. A number of European allies are indeed much more interested in NATO and their special relations with the US for ensuring national security than to invest in a still confuse PESCO. The strategic dilemma could become a perfect one because 'there are a number of states, including Romania and Poland, to mention just the most important ones on the Eastern Flank, that have strategic partnerships with the US and probably they would not renounce to the primordial role of their transatlantic relations for ensuring own security. [...] But the reform of the European Union and PESCO could one day oblige all member states to military procurements from the EU sources, based on a kind of Buy European Act, and such a measure would clearly disengage the US from Europe and weaken NATO' (Naumescu apud Manea, 2017, pp. IV-V). The same cautious approach is assumed by Ulrike Esther Franke: 'PESCO is a project that the German government welcomed as 'a big step towards [European] self-reliance' (Foreign Minister Sigmar Gabriel), and 'another step in the direction of the Army of Europeans' (Defense Minister von der Leyen). [...] The disparity in perception is alarming. Germans are proud of how far they have come. But European allies are starting to roll their eyes when they hear this narrative' (Franke, 2017).

Two main types of political approaches have been developed so far. Taking into consideration all positions mentioned before, the support for PESCO is either enthusiastic/radical, as it is in Brussels, in France and Germany (especially in the Social Democratic Party of Germany) and in the hard core of the EU, or moderate/cautious, like in Poland, Baltic States and Romania and at NATO level. The choir of the enthusiasts is opened obviously by Jean Claude Juncker, the President of the European Commission: 'She is awake, the Sleeping Beauty of the Lisbon Treaty: Permanent Structured Cooperation is happening. I welcome the operational steps taken today by 
Member States to lay the foundations of a European Defense Union. Europe cannot and should not outsource our security and defense' (Deutsche Welle, 2017). In this entire fluid international context, it is rather interesting to observe that even the repudiated Turkey has some hopes regarding PESCO. Asking whether PESCO could help revive Turkey-EU relationship, Anadolu Agency believes that 'joint defense cooperation among EU states might eliminate ongoing challenges that led to serious ruptures between Turkey and the EU' (Noi, 2017). So far there are no indications that candidate states such as Turkey or others could be accepted in PESCO, as full members or with a special status.

With regard to the projects and the administrative dimension, 17 joint defense projects were earmarked as eligible under the PESCO framework. Germany will be most probably leading four projects: the creation of a pan-European medical unit, a logistics hub, a center for training missions and an initiative to build up faster crisis response forces (Deutsche Welle, 2017). The final projects are expected to be officially adopted in the first months of 2018, with participating countries also invited to propose additional programs. The scarcity of information and the lack of details on the governance and administrative aspects of PESCO is an indication that things are still under discussion and nothing is clear. The only two points formulated at the Council in December concern 'the PESCO governance, with an overarching level maintaining the coherence and the ambition of the PESCO, complemented by specific governance procedures at projects level and the administrative arrangements, including the secretariat functions for PESCO at project level and financing' (The European Council, 2017).

It is self-evident that PESCO is theoretically consistent with the logic of European integration and 'more Europe'. What is somehow surprising is that PESCO was approved and launched although the founding principle of 'ever closer Union' was heavily contested in the past years in some EU Member States, even in the founding states such as France, Germany and the Netherlands, not to mention the four members of the Visegrad Group. In spite of this reluctance, 25 out of the 27 remaining countries have just decided to join this ('revolutionary'?) initiative. Having in mind the recent positioning of the EU countries in relation to Brussels and EU policies, we can presume two possible explanations for this massive affiliation. The first reason is related to the idea of the beginning of the EU reform and the formation of a 'hard core', so that nobody knows what comes next and does not take the risk to stay out of the process. The second possible explanation refers to the strategy of some Eurosceptic countries such as Poland to be 'in' in order to keep control on further developments within the European Union, reserving their right to veto any future measure of European military integration. In fact, none of these two possible explanations of the massive start of PESCO is fully encouraging when it comes to its perspectives.

\section{Conclusion: Incremental scenario vs. 'much ado about nothing'}

The Permanent Structured Cooperation in the field of defense, both as a concept and as a policy/practice, is clearly related to the idea of the reform of the Europe- 
an Union. Unlike other waves of the EU reforms, already mentioned in the article, the current one is related to an existential crisis of the Union and therefore seems/ is much more politicized and identity-oriented. For the moment, the administrative and governance dimensions of PESCO do not disclose enough details to understand the real direction where this process goes. Most probably 2018 and early 2019, before the elections for the European Parliament, will bring clarifications regarding the management and the limits of the Defense Union. The long and difficult negotiations for the formation of the new German government and the political uncertainty in Berlin postponed in the fall of 2017 the implementation of substantial steps towards the edification of the common European defense.

PESCO is indeed an 'evolving concept', as it was explained by the EU leaders from the beginning, but the dynamic character cannot be accepted as the only reason for the vagueness of this initiative. Different authors and experts already signal this concerning aspect: 'the key question revolves around how to define those states which are willing and able. Yet many provisions of PESCO are vague when it comes to actual cooperation [...] 'Inclusivity' and 'modularity' have emerged as guiding principles.' [...] The implementation of PESCO depends therefore on the translation of these two concepts into concrete terms' (De France, Major and Sartori, 2017, p. 5).

From one Treaty to another and from one integration project to the next one, the European Union became more and more preoccupied to develop its specific identity and to emphasize self-defining characteristics. The political will of Brussels for identity consolidation and strategic autonomy grew significantly from the Maastricht Treaty to the Lisbon Treaty then to its PESCO's launch in 2017, despite a parallel process of a rising Euroscepticism. Both visions have thus radicalized their proposals and 'solutions'. Elena Korosteleva believes that 'rhetorical projections have considerable intensified, from 2011 entering into a competitive mode for a 'Grand Vision' for Europe. [...] Consequently, the projects have become incompatible for the third parties imposing a choice of allegiances and the need of subscription for one of the established regimes' (Korosteleva, 2017, p. 7). According to this perspective of radicalization, PESCO could act in the near future as a differentiator between the pro-EU and the pro-US Member States, even though we speak about countries that are simultaneously EU and NATO Member States.

The growing level of strategic ambition of the EU's hard core to build the Defense Union could act in the future both as an asset and vulnerability for PESCO. It could be an asset, because it is fully connected with the idea of deepening European integration and saving the European Project amidst the present crisis. It could be also a form of vulnerability, because it is interfering with the most sensitive aspect regarding the strategies of the sovereign states, namely the national security and defense. Depending on historic, geopolitical and even cultural considerations, the EU Member States have deeply different perspectives on their national security.

Two main scenarios emerge with regard to PESCO. The optimistic view could be described as 'the incremental scenario', in which the EU will make gradual progress 
and achieve its strategic aim in a step-by-step approach. This view is shared especially in France, Germany, in other states of the hard core of the European Union and obviously in Brussels. The election of Emmanuel Macron as President of France and the reconfirmation of Angela Merkel as Chancellor of Germany in 2018 are seen as the most powerful guarantees for the advance of PESCO.

On the contrary, the 'much ado for nothing' scenario is shared in the outgoing United Kingdom but also in Poland, the biggest country of the post-communist Central Europe. Nick Witney puts it in the terms of an old Chinese say: 'big noise on stairs, nobody coming down' (Witney, 2017). The former British Defense Secretary Michael Fallon affirms without equivoque that 'defense is for NATO not for EU' (Fallon, 2017). The Polish Foreign Minister is also clear: 'Europe already has an alliance, it is called NATO. The question is whether we really need to have a second defense structure in the EU, especially when NATO's calls to spend 2\% of GDP on defense systems are only fulfilled by five countries and only a few European countries, such as Poland' (Waszczykowski, 2017).

Between the enthusiast and the reluctant EU member states there is also a third category of moderate countries, cautiously supporting PESCO but vigilantly reiterating their full commitment to NATO and to the strategic partnership with the United States. Romania and the Baltic States are the most representative countries for this category, not as noisy as Poland but actually much closer to a pro-US doctrine of security.

PESCO and the new reform of the European Union come in a critical moment of the European Project, when the first EU member is to leave the Union, following a popular vote. More than just a theoretical approach of a deepening European integration but less than an effective, clearly explained and feasible policy, the Defense Union is still struggling between the 'wishful thinking' of the hard core and the limits of political will and military capabilities of the EU member states.

\section{References:}

1. Alexandrova, P., Rasmussen, A. and Toshkov, D., 'Agenda Responsiveness in the European Council: Public Priorities, Policy Problems and Political Attention', 2015, West European Politics, vol. 39, no. 4, pp. 605-627.

2. Balint, T., Bauer, M.W. and Knill, C., 'Bureaucratic Change in the European Administrative Space: The Case of the European Commission', 2008, West European Politics, vol. 31, no. 4, pp. 677-700.

3. Bauer, M.W., 'Impact of Administrative Reform of the European Commission: Results from a Survey of Heads of Unit in Policy-Making Directorates', 2009, International Review of Administrative Sciences, vol. 75, no. 3, pp. 459-472.

4. Bølstad, J., 'Dynamics of European Integration: Public Opinion in the Core and Periphery', 2015, European Union Politics, vol. 16, no. 1, pp. 23-44.

5. Bovaird, T., 'Researching Europeanisation in Public Administration and Policy: Conceptual Issues in Integration and Differentiation', in Nemec, J. (ed.), Europeanisation in Public Administration Reforms, Bratislava: NISPAcee Press, 2016, pp. 13-22. 
6. Cardona, F. and Freibert, A., 'The European Administrative Space and Sigma Assessments of EU Candidate Countries', 2007, Croatian and Comparative Public Administration, vol. 7, no. 1, pp. 51-59.

7. Council of the European Union, 'Council Conclusions on the Global Strategy on the European Union's Foreign Policy and Security', 13202/16, CFSP/PESC 814, CSDP/ PSDC 572, October 17, 2016, [Online] available at http://data.consilium.europa.eu/doc/ document/ST-13202-2016-INIT/en/pdf, accessed on December 12, 2017.

8. Council of the European Union, 'Notification on Permanent Structured Cooperation (PESCO) to the Council and to the High Representative of Union for Foreign Affairs and Security', November 17, 2017, [Online] available at https://www.consilium.europa.eu/media/31511/171113-pesco-notification.pdf, accessed on December 12, 2017.

9. De Bruycker, I., 'Politicization and the Public Interests: When Do the Elites in Brussels Address the Public Interests in EU Policy Debates?', 2017, European Union Politics, vol. 18, no. 4, pp. 603-619.

10. De France, O., Major, C. and Sartori, P., 'How to Make PESCO a Success', Ares (Armament Industry European Research), Group Policy Papers no. 21, September 2017, [Online] available at http://www.iris-france.org/wp-content/uploads/2017/09/Ares-21Policy-Paper-Sept-2017.pdf, accessed on December 12, 2017.

11. European Union External Action (EEAS), 'Permanent Structured Cooperation (PESCO) - Factsheet', November 16, 2017, [Online] available at https:/eeas.europa.eu/ headquarters/headquarters-homepage_en/34226/Permanent\%20Structured\%20Coope ration\%20(PESCO)\%20-\%20Factsheet, accessed in December 12, 2017.

12. Fallon, M., Interview for Deutsche Welle, 'Defense is for NATO not for EU', Deutsche Welle, 18 February 2017, [Online] available at http://www.dw.com/en/fallon-defenseis-for-nato-not-for-eu/av-37615331, accessed on December 12, 2017.

13. Finke, D., König, T., Proksch, S.O. and Tsebelis, G., Reforming the European Union: Realizing the Impossible, New Jersey: Princeton University Press, 2012.

14. Finn, C., 'Dáil Votes for Ireland to Join Pesco EU Military Defense Pact', article published in The Journal, December 7, 2017, [Online] available at http://www.thejournal. ie/pesco-eu-ireland-3738016-Dec2017/, accessed on December 12, 2017.

15. Franke, U.E., 'Pesco, the Impotent Gorilla', European Council on Foreign Relations, November 17, 2017, [Online] available at http://www.ecfr.eu/article/commentary_pes co_the_impotent_gorilla, accessed on December 12, 2017.

16. Haas, E.B., The Uniting of Europe: Political, Economic and Social Forces 1950-1957, Stanford: Stanford University Press, 1958.

17. Hix, S., What's Wrong with the European Union and How to Fix It, Cambridge: Polity Press, 2008.

18. Deutshe Welle, 'PESCO: EU Army One Step Closer after Defense Pact Agreement', December 11, 2017, [Online] available at https:/www.dw.com/en/pesco-eu-army-onestep-closer-after-defense-pact-agreement/a-41741828, accessed on May 12, 2018.

19. Kassim, H., 'Mission Impossible, but Mission Accomplished: The Kinnock Reforms and the European Commission', 2008, Journal of European Public Policy, vol. 15, no. 5, pp. 648-668.

20. Kassim, H., Peterson, J., Bauer, M.W., Connolly, S., Dehousse, R., Hooghe, L. and Thompson, A., The European Commission in the 21st Century, Cambridge: Cambridge University Press, 2010. 
21. Korosteleva, E., 'Putting the EU Global Strategy to Test: 'Cooperative Orders' and Othering in EU-Russia Relations', 2017, International Politics, (online first), pp. 1-17.

22. Mănoiu, C., 'Aurescu, despre PESCO: Nu vom vedea o armată europeană care să ia locul NATO' (Aurescu, about PESCO: We Will Never See an European Army to Replace NATO), article for Mediafax, November 3, 2017, [Online] available at http:// www.mediafax.ro/politic/aurescu-despre-pesco-nu-vom-vedea-o-armata-europea na-care-sa-ia-locul-nato-16806063, accessed on December 12, 2017.

23. McNamara, K.R., 'What to Read on the European Union', Foreign Affairs, March 9, 2010, [Online] available at https://www.foreignaffairs.com/articles/europe/2010-03-09/ what-read-european-union, accessed on November 22, 2017.

24. Ministry of National Defense of Poland, 'Meeting of the Defense Ministers of the European Union', November 13, 2017, [Online] available at http://en.mon.gov.pl/news/ article/latest-news/meeting-of-defense-ministers-of-european-union-c2017-11-17/, accessed on December 12, 2017.

25. Moravcsik, A., The Choice for Europe: Social Purpose and State Power from Messina to Maastricht, Ithaca, NY: Cornell University Press, 1998.

26. NATO, 'Origins. NATO Leaders', [Online] available at https:/www.nato.int/cps/su/ natohq/declassified_137930.htm, accessed on December 12, 2017.

27. Manea, O., 'Valentin Naumescu: Washingtonul între nucleul dur și crizele Estului' (Valentin Naumescu: Washington Between Hard Nucleus and Crises of the East), Revista 22, October 17, 2017, [Online] available at https://revista22.ro/interviu/valen tin-naumescu-washingtonul-intre-nucleul-dur-si-crizele-estului, accessed on September 21, 2018.

28. Noi, A.I. 'Can PESCO Help Revive Turkey-UE Relationship?', Anadolu Agency, December 11, 2017, [Online] available at http://aa.com.tr/en/analysis-news/analysis-canpesco-help-revive-turkey-eu-relationship-/1001607, accessed on December 2017.

29. Ongaro, E., 'The Administrative Reform Trajectory of the European Commission in Comparative Perspective: Historical New Institutionalism in Compound Systems', 2013, Public Policy and Administration, vol. 28, no. 4, pp. 346-363.

30. Peet, J. and La Guardia, A., Unhappy Union: How the Euro Crisis and Europe Can Be Fixed, London: The Economist in Association with Profile Books Ltd., 2014.

31. Pierson, P., 'The Path to European Integration: A Historical Institutionalist Analysis', 1996, Comparative Political Studies, vol. 29, no. 2, pp. 123-163.

32. Rettman, A., 'France and Germany Propose EU 'Defense Union', September 12, 2016, [Online] available at https://euobserver.com/foreign/135022, accessed on November 19, 2017.

33. Reuters, 'France's Macron Calls for 'Refoundation' of Sovereign, United Europe', September 26, 2017, [Online] available at https://uk.reuters.com/article/uk-france-eu-ma cron-sovereignty/frances-macron-calls-for-refoundation-of-sovereign-united-eu rope-idUKKCN1C11X0, accessed on November 26, 2017.

34. SIGMA, 'SIGMA at a Glance', [Online] available at http://www.sigmaweb.org/about/, accessed on November 27, 2017.

35. Spence, D.B., 'The Directorates General and the Services: Structures, Functions and Procedures', in Spence, D.B. and Edwards, G. (eds.), The European Commission, London: John Harper Publishing, 2006, pp. 128-155. 
36. Stoltenberg, J., 'Doorstep by NATO Secretary General Jens Stoltenberg at the Start of the European Union Foreign Affairs Council in Defense Format', NATO Newsroom, November 13, 2017, [Online] available at https://www.nato.int/cps/en/natohq/opini ons_148840.htm, accessed on December 12, 2017.

37. The European Council and Council of the European Union, 'Defense Cooperation: Council Establishes Permanent Structured Cooperation (PESCO), with 25 Member States Participating', December 11, 2017, [Online] available at http://www.consilium. europa.eu/en/press/press-releases/2017/12/11/defence-cooperation-pesco-25-mem ber-states-participating/, accessed on December 12, 2017.

38. Toshkov, D., 'Public Opinion and Policy Output in the European Union: A Lost Relationship', 2011, European Union Politics, vol. 12, no. 2, pp. 169-191.

39. Waszczykowski, W., 'We Joined PESCO but with Doubts', Ministry of Foreign Affairs of the Republic of Poland, November 13, 2017, [Online] available at http://www. msz.gov.pl/en/news/they_wrote_about_us/minister_witold_waszczykowski__we_ joined_pesco_but_with_doubts_pap_dispatch_from_13_november_2017_;session id=8E5E3F9C275CE0F5B1E044205177209A.cmsap1p, accessed on December 12, 2017.

40. Witney, N., 'EU Defense Efforts Miss the Open Goal Again', European Council on Foreign Relations, November 15, 2017, [Online] available at http://www.ecfr.eu/article/ commentary_eu_defence_efforts_miss_the_open_goal_again, accesses on December 12, 2017. 